\section{Adaptation of Teacher Retention Scale into Turkish \\ Culture: A sudy of validity and reliability ${ }^{1}$}

Öğretmenin Okulda Kalma Tutumu Ölçeğinin Türk Kültürüne uyarlanması: Geçerlik ve güvenirlik çalışması

\author{
Ayça Kaya ${ }^{2}$ \\ Türkan Argon ${ }^{3}$
}

\section{Özet}

Bu araşturma ile Joyce Marie Brydson Alexander (2010) tarafindan geliştirilen Öğretmenin Okulda Kalma Tutumu Ölçeği'nin öğretmenler üzerinde Türkçe'ye uyarlanması çalışması yapılmıştır. Dil geçerliği aşamasında ölçeğin Türk kültürüne uyarlanmasında öncelikle çeviri, geri-çeviri ve uzman görüșü yöntemlerine başvurulmuştur. Daha sonra ölçeğin dil eşdeğerliği için dilsel eşdeğer form uygulaması yapilmıştır. Ölçeğin dilsel eşdeğerliğinin test edilmesinde İngilizce öğretmenlerine belirli aralıklarla (İngilizce-Türkçe; Türkçe-İngilizce) uygulama yapılmış; İngilizce ve Türkçe formların puanları arasinda pozitif ve anlamlı korelasyonlar olduğu saptanmıştur. Ölçeğin faktör yapısının belirlenmesi amaciyla uygulanan açımlayıcı ve doğrulayıcı faktör analizleri sonucunda ölçeğin 6 maddeden oluşan tek boyutlu bir yap1 gösterdiği ortaya konulmuştur. Öğretmenin Okulda Kalma Tutumu Ölçeği için yapilan madde toplam korelasyon katsayılarının ,584-,769 arasında değiştiği ve bu katsayıların istenen düzeyde olduğu görülmüştür. Ayrica faktör yük değerlerinin ,671 ile ,835 arasinda olduğu ortaya çıkmıştır. Ölçeğin Cronbach Alpha iç tutarlilık katsayısı $(\alpha=.889)$

\footnotetext{
${ }^{1}$ This research was generated by Ayça Kaya from a PhD Thesis, which was accepted by BAIBU Institute of Educational Sciences under the consultancy of Prof. Dr. Türkan ARGON in 2019.

2 Ph.D., ayca.bagmen@hotmail.com

${ }^{3}$ Prof. Dr., Bolu Abant İzzet Baysal University, Faculty of Education, turkanargon@hotmail.com
} 
Kaya, A., \& Argon, T. (2019). Öğretmenin Okulda Kalma Tutumu Ölçeğinin Türk Kültürüne uyarlanması: Geçerlik ve güvenirlik çalışması. Journal of Human Sciences, 16(4), 1180-1196. doi:10.14687/ihs.v16i4.5801

$(\alpha=.889)$. The variation between Upper and Lower groups measured as $27 \%$ has been found meaningful. The factor structure obtained via Exploratory Factor Analysis has been verified by the outcomes of Confirmatory Factor Analysis in terms of item statistics except for item no 2 and item no 5. Confirmatory Factor Analysis suggests that the factor load values vary from ,37 to ,91. These values have been interpreted as medium and high factor loads. In addition, the values regarding multiple correlation (R2) vary from 14 to ,83. Thus, it has been found that R2 value is at high and mediocre levels. It has also been demonstrated that X2/df, RMSEA and NNFI values were not at desired levels prior to modification and that the values of goodness of fit (items 4-6) have been pulled up to desired levels following the modification. It has also been found that retention views levels correspond to "I agree" level. In conclusion, Teacher Retention Scale is a unidimensional scale of 6 items as well as a valid and reliable testing instrument.

Keywords: Teacher retention scale; adaptation; validity; reliability; teacher.

(Extended English summary is at the end of this document) hesaplanmıştır. Alt-Üst \%27'lik gruplar arasındaki fark anlamlı bulunmuştur. AFA sonucunda elde edilen faktör yapısı madde 2 ve madde 5 haricinde madde istatistikleri açısından DFA bulguları ile doğrulanmıştır. DFA sonucunda maddelerin faktör yük değerlerinin ,37 ile, 91 arasında değiştiği tespit edilmiştir. Söz konusu değerler orta ve yüksek faktör yükü olarak değerlendirilmiştir. Öte yandan çoklu korelasyon karesine ilişkin değerler (R2), 14 ile ,83 arasında değişmektedir. Bu nedenle R2 değerinin yüksek ve orta düzeyde olduğu görülmüştür. Ayrıca modifikasyon öncesi X2/df, RMSEA ve NNFI değerlerinin istenilen ölçütte olmadığ1; ancak yapilan modifikasyonlardan sonra (Madde 4-6) uyum iyiliği değerlerinin istenilen seviyeye çıktığ görülmüştür. Ayrıca öğretmenlerin okulda kalma tutumları görüşlerinin "katıllyorum" düzeyine karşllık geldiği görülmüştür. Sonuç olarak, Öğretmenin Okulda Kalma Tutumu Ölçeği'nin toplam 6 maddeden oluşan tek boyutlu geçerli ve güvenilir bir ölçme aracı olduğu sonucuna ulaşılmıştır.

Anahtar Kelimeler: Öğretmenin okulda kalma tutumu ölçeği; uyarlama; geçerlik; güvenirlik, öğretmen.

\section{Giriş}

Öğretmenlerin okulda kalma tutumları, günümüz eğitim politikalarında gündeme oturarak irdelenmeye başlayan konular arasında yerini almaya başlamıştır. Öğretmenlerin okulda kalması için öğretmenlerin kalitelerinin artırılmasına yönelik çalışmalar yapılması, bu öğretmenlerin ihtiyaçlarına önem verilmesi ve güçlü bir eğitim kadrosu oluşturmada çeşitli çağdaş stratejilerin uygulamaya koşulması öğretmenlerin okulda kalma kararlarını pozitif yönde etkileyebilir. Federal Amerika'da yapılan bir çalışma, eyalet ve yerel politika yapıcılar ve eğitim liderlerinin, bütün devlet okullarının sinıfinda kaliteli öğretmenler sağlamaya ve bunları okulda tutmaya çaba göstermesi gerektiğini belirtmektedir (Johnson, Birkeland, Kardos, Kauffman, Liu \& Peske, 2005). Bununla birlikte, devlet okulları büyük bir öğretmen sıkıntısı yaşamaya devam etmekte ve pek çok ders, öğrettikleri alanda sertifikalı olmayan öğretmenlerle doldurulmaktadır (Russell, 2005). Düşük öğrenci başarısı ile yüksek öğretmen devir hızı oranları arasında doğrudan bir ilişki olduğu için öğretmen yetersizliği sorunu, öğrenci başarısını etkilemektedir (Grier \& Holcombe, 2008; Howard, 2003; Smith \& Smith, 2006). Benzer şekilde ilk ve orta dereceli devlet okulları son yirmi yıldır öğretmen sıkıntısı çekmektedir (Ingersoll, 2001). Yapılan bu çalışmaların sonucu, öğretmen kalitesine ve kaliteli öğretmenlerin varllğına dikkat çekmiştir. Williams (2007), öğretmen kıtlığı krizini çözmek için öğretmenin okulda kalmasının hayati önemde olduğunu ileri sürmüş; öğretmenlerin okulda kalmasının sadece parasal tasarruf sağlamakla kalmayıp aynı zamanda çocukların eğitimsel geleceğinin korunmasına da katkıda bulunacağını ifade etmiştir. Öğretmenlerin okulda kalma durumlarında, kişisel ve mesleki artı ve 
Kaya, A., \& Argon, T. (2019). Öğretmenin Okulda Kalma Tutumu Ölçeğinin Türk Kültürüne uyarlanması: Geçerlik ve güvenirlik çalışması. Journal of Human Sciences, 16(4), 1180-1196. doi:10.14687/jhs.v16i4.5801

eksilerini düşünmeleri, birçok araştırmanın ortak konusudur. Bu artı ve eksiler yalnızca maaş ve sosyal haklarla ilgili olmadığı gibi, aynı zamanda eğitim dünyasındaki paydaşlarıyla kurulan ilişkiler, okul ortamından beklenti ve memnuniyet ile paydaşların özellikle de liderin öğretmene karşı tutumuyla ilgilidir (Mancuso, 2010). Mancuso'ya (2010) göre, Amerika Birleşik Devletleri'nde yapılan araştırmalarda, öğretmenlerin okulda kalma ve okulu terk etme durumlarında okul liderlerinin büyük ölçüde paylarının olduğu anlaşılmıştır. Bu anlamda öğretmenleri destekleyen bir eğitim liderliği anlayışı, öğrencilerin eğitimlerindeki kalitenin artması bağlamında önem taşımaktadır. Eğitim liderleri öğretmen eksikliklerini kapatmak için çabalarken, öğretmenlerin mesleki gelişimlerini engelleyen geleneksel liderlik uygulamalarından kaçınmaya da çok dikkat etmelidirler (Dove, 2004; Ingersoll, 2001; Winans, 2005). Dolayısıyla öğretmenlerin mesleki gelişimlerine firsat sunan ortamlar yaratmak, yönetimin sorumluluğundadır. Böyle bir anlayış, öğretmenlerin okulda kalmalarını sağlayan etmenlerden biri olabilir.

Araştırmacılar, öğretmen yetersizliği sorununun bir çözümü olarak, öğretmenin okulda kalma tutumunu desteklemişlerdir (Carroll \& Fulton, 2004). Bununla birlikte, süreçte etkili bir değişken olarak okul yöneticileri bağlamında pek çok okul lideri, öğretmenin okulda kalması için etkili stratejiler geliştirmede başarısız kalmaktadır. Bu bakımdan çeşitli araştırmacılar öğretmenlerin okulda kalma koşullarını iyileştirmek için yeni stratejiler aramaktadır (Dove, 2004). Öğretmenin okulda kalma oranlarını yüksek tutma eğilimi gösteren okul liderleri, öğretmenleri profesyonel olarak değerli kılan, liderlik rollerini paylaşan, yaratıcılıklarını kullanmalarına ve müfredat, öğretim stratejileri ve disiplinle ilgili kararlar almalarına yardımcı olan kişilerdir (Russell, 2005). Winans (2005) da benzer şekilde müfredata, disipline ve çalışma koşullarını etkileyen diğer konulara ilişkin öğretmenlere profesyonel ses vermenin, onların okulda kalma oranlarını artıracağını öne sürmektedir. Okul yöneticileri, öğretmenlerin mesleklerine saygı gösterip onları okulda karar verme süreçlerine katarak ve uygun şekilde destekleme konusunda yeterli zaman sağlayarak, öğretmenlerin çalışma koşullarını olumlu yönde etkileyebilirler. Çünkü çalışma koşulları olumlu ve iyi olan öğretmenlerin mesleklerinde kalma olasıllkları daha yüksektir (The Learning Point Associates, 2007). Diğer yandan okul yöneticileri, öğretmen kıtllğı krizine çare olarak öğretmenin okulda kalması konusunda güçlü bir destek vermeli, öğretmenleri etkili bir şekilde uygulamaya geçirmeli veya öğretmenleri okulda tutma yolları aramalıdır (Patton, 2006). Okul liderleri, paylaşılan liderlik uygulamasını, öğretmenlerin okulda tutulmasını iyileştirmek için etkili bir strateji olarak düşünmelidirler. Zira paylaşılan liderlik, öğretmenlerin çalışma koşullarına ve öğretim uygulamalarına göre okula dayalı kararlar verebilme yeteneğini güçlendirmektedir (Dove, 2004; Winans, 2005). Çünkü çalışma koşulları iyileştirilmiş bir çalışanın, örgütünde kalmaya devam etme olasıllğının daha yüksek olduğu öngörülmektedir (Winans, 2005). Alanyazında çalışanı elde tutma (employee retention) olarak kullanılan bu kavram, eğitim literatüründe öğretmenin okulda kalma tutumu (teacher retention) biçiminde isimlendirilebilir. Bu doğrultuda okullarda eğitim yöneticileri, öğretmenlere mesleklerine uygun bir şekilde hazırlanmak için yeterli zamanı sağlayarak, onların çalışma koşullarını olumlu yönde etkileyebilirler (Şekerci ve Aypay, 2009). Zira araştırmalar; işyeri koşulları iyileştirildiğinde, öğretmenlerin mesleklerini sürdürme ve mesleklerinde kalma olasılıklarının daha yüksek olduğunu göstermektedir (The Learning Point Associates, 2007). Yapılan araştırmalardan bazıları da (Dantonio, 2001; Ellison, 2005) yönetimin, öğretmenlerin gelişimini destekleyerek okulun bir öğrenme topluluğuna dönüştürülmesini sağlamasının, öğretmenlerin okulda kalıcılı̆̆ını arttırdığını ileri sürmektedir. Türkiye'de ise sürekli değişen eğitim politikaları, uygulamadaki zorluklar, fiziksel koşulların eksikliği, öğretmenlerin içinde bulunduğu yaşam koşullarının yetersizliği, veli beklentileri, yönetimin istekleri, öğrencilerle yaşanan problemlerin su yüzüne çıkmasına engel olan çeşitli faktörler gibi pek çok neden, öğretmenlerin okulda kalmaya karşı tutumlarını olumsuz yönde etkileyebilmektedir.

Öğretmenlerin okulda kalmaya ya da mesleklerine devam etmeye karar verebilmeleri Türkiye'de çokça karşılaşılan bir durum olmamakla birlikte, özellikle zorunlu hizmet bölgelerinde kalmaya devam etmeye talep olmaması ya da özel okullarda çalısan öğretmenlerin sıklıkla yer değiştirme isteklerinin gündemde olması ülkemiz koşullarında bu konuyu irdelemeye değer hale 
Kaya, A., \& Argon, T. (2019). Öğretmenin Okulda Kalma Tutumu Ölçeğinin Türk Kültürüne uyarlanması: Geçerlik ve güvenirlik çalışması. Journal of Human Sciences, 16(4), 1180-1196. doi:10.14687/jhs.v16i4.5801

getirmiştir. Bu durum, öğretmenlik mesleği dışında alternatif bir mesleğe yönelmede yaşanan zorlukların etkisi olabileceğini düşündürmektedir. Bu durum öğretmenlerin yaşadıkları sorunlar nedeniyle iyi statüde bir iş imkânı bulunması durumunda yeniden öğretmen olmayı tercih etmeyecekleri araştırma bulgusuyla örtüşmektedir (Kaysi ve Gürol, 2016). Zira öğretmenlerin mesleğe başladıktan sonra mesleğin zorlu koşullarına rağmen öğretmenlik yaşamlarını sürdürdükleri söylenebilir. Bu doğrultuda yapılan bu çalışma ile Öğretmenin Okulda Kalma Tutumu Ölçeğinin Türk kültürüne uyarlanması; öğretmenlerin okulda kalma düzeylerini belirlemek; öğretmenlerin okulda kalmaya devam etmelerinde, farklı okullara gitmelerinde veya emeklilikten önce mesleği terketmelerinde rol oynayabilecek faktörlerin belirlenmesi ve ulusal alanyazındaki birçok farklı kavramla ilisskilendirilmesinin sağlanması açısından yapı oluşturarak öğretmenin okulda kalmasını etkileyen ve etkilendiği durumların tespit edilmesi bağlamında önemli görülmektedir. Bu doğrultuda yapılan çalışma ile Brydson Alexander (2010) tarafindan geliştirilen Öğretmenin Okulda Kalma Tutumu Ölçeğinin Türkçeye uyarlaması yapılarak, ölçeğin Türk kültüründe geçerli ve güvenilir bir ölçme aracı olarak kullanımı amaçlanmıştır.

\section{Yöntem}

\section{1. Çalışma Grubu}

Araştırma 2018-2019 eğitim- öğretim yılında Kocaeli ve İstanbul illerinde görev yapan öğretmenlerle (iki farklı çalışma grubu) yürütülmüştür. Ölçeğin yapı geçerliğini test etmek amaciyla önce birinci örneklem grubu ile Açımlayıcı Faktör Analizi (AFA) aracıllğıyla bir model oluşturulmuş; sonra ikinci örneklem grubu ile Doğrulayıcı Faktör Analizi (DFA) yapılarak ölçeğin yapısının doğrulanıp doğrulanmayacağı belirlenmiştir (Orçan, 2018). Bu doğrultuda araştırmanın ilk çalışma grubunu Kocaeli ilinde çalışan 400 öğretmen oluşturmaktadır. Bu gruptaki öğretmenlerin \%55’inin erkek, \%45'inin kadın olduğu; \%29,5'inin 21-30 yaş, \%40,5'inin 31-40 yaş, \%20'sinin 41-50 yaş aralığında, \%10'unun 51 ve üzeri yaşında olduğu belirlenirken; katılımciların \%59,3’ünün evli, \%40,7'sinin bekar olduğu tespit edilmiştir. Katıllımcıların \%42,2'ü ilkokulda görev yapmakta, \%27,3’ü ortaokulda, \%30,5’i lisede görev yapmaktadır. Katılımcıların genellikle mesleki kıdeminin 6-10 yıl olduğu okuldaki çalışma süresinin ise 1-5 yl aralığında olduğu belirlenmiştir. Katulımcıların \% 72,3’ü lisans \%27,8'inin lisansüstü mezunu olduğu, \%75,0’inin eğitim fakültesinden mezun olduğu, \%21,5'inin fen/edebiyat fakültesinden mezun olduğu, \%3,5’inin ise diğer fakültelerden mezun olduğu görülmüş̧ür. Katılımcıların \%17,5'inin maaşlarından memnun olduğu, \%56,5’inin kısmen memnun, \%26'sının maaşlarından memnun olmadığı görülmüştür. İkinci çalışma grubu İstanbul ilinde çalışan 518 öğretmenden oluşmuştur. Bu gruptaki öğretmenlerin \%32,6'sının erkek, \%67,4'ünün kadın olduğu; \%33,2'sinin 21-30 yaş, \%47,7'sinin 31-40 yaş, \%13,3'ünün 41-50 yaş aralı̆̆ında, \%5,8'inin 51 ve üzeri yaşında olduğu belirlenirken; katıllmmciların \%67,2'sinin evli, \%32,8’inin bekar olduğu görülmüştür. Katılımcıların \%32,2'si ilkokulda görev yapmakta, \%27'si ortaokulda, \%40,7'si lisede görev yapmaktadır. Katılımcıların genellikle mesleki kıdeminin ve okuldaki çalışma süresinin 1-5 yıl olduğu belirlenmiştir. Katıllmcılanın \%76,8’i lisans, \%23,2'sinin lisansüstü mezunu olduğu, \%51,7'sinin eğitim fakültesinden mezun olduğu, \%36,5'inin fen/edebiyat fakültesinden mezun olduğu, \%11,8’inin ise diğer fakültelerden mezun olduğu görülmüştür. Katllımcıların \%12,9’unun maaşlarından memnun olduğu, \%50,2'sinin kısmen memnun, \%36,9’unun maaşlarından memnun olmadığ1 görülmüştür.

Araştırmada çalışma gruplarına ulaşılmasında iki uygulama için de web üzerinden www.google.com adresinin bir uygulaması olan "Google formlar" yazılımında yapılan anket sistemi kullanılmıştır. İnternet üzerinden oluşturulmuş olan bu araştırma bağlantısı ölçeğin nasıl yanıtlanacağına ilişkin detaylı bir açıklama notu ile birlikte araştırmacıların e-posta adreslerine yollanmıştır. Ulaşılabilen katılımcılar aynı zamanda sözel olarak bilgilendirilmiş ve gönüllü olarak katılmaları doğrultusunda araştırmaya dâhil edilmişlerdir. Çalışmaya katılan kişinin tekrar tekrar formu doldurmasının önüne geçebilmek için katılımcının IP numarasına sınırlama getirilmiş ve aynı bilgisayar ya da akıllı telefondan birden fazla kez katılımı önlenmiştir. Katılımcıların demografik 
Kaya, A., \& Argon, T. (2019). Öğretmenin Okulda Kalma Tutumu Ölçeğinin Türk Kültürüne uyarlanması: Geçerlik ve güvenirlik çalışması. Journal of Human Sciences, 16(4), 1180-1196. doi:10.14687/jhs.v16i4.5801

bilgileri dışında herhangi bir kimlik bilgisi alınmamıştır. Ayrıca veri toplama süreci ilk çalışma grubu için 4 hafta, ikinci çalş̧ma grubu için de 4 hafta süreyle toplamda 8 hafta boyunca devam etmiştir. Araştırmada, AFA için SPSS for Mac OS 22.0, DFA için Lisrel 8.7 kullanılmış ve araştırma sürecinde anlamll1k düzeyi .05 kabul edilmiştir.

\section{2. Ölçme Aracı}

"Öğretmenin Okulda Kalma Tutumu Ölçeği” katılımcıların okullarında kalmayı ya da gitmeyi neden tercih ettiklerini belirlemek amaciyla Joyce Marie Brydson Alexander (2010) tarafindan geliştirilmiştir. Araştırmac1 ölçeği geliştirirken "Massachusetts Eğitim, Öğrenme ve Liderlik Anketi"nden yararlanmıştır (Massachusetts Eyalet Eğitim Bakanlığı, 2008). 8 madde ve tek boyuttan oluşan bu ölçek "Kesinlikle Katılmıyorum" (1), "Katılmıyorum" (2), "Kararsızım" (3), "Katıliyorum" (4) ve "Kesinlikle Kattlıyorum" (5) biçiminde derecelendirilmiş 5’li Likert tipi bir ölçme aracıdır. Ölçeğin Cronbach Alpha güvenirlik katsayısının $\alpha=.75$ olduğu ifade edilmiştir.

\subsection{Dil Geçerliği}

Öğretmenin Okulda Kalma Tutumu Ölçeğinin uyarlama çalışması için ölçeği geliştiren araștırmacılardan olan Joyce Marie Brydson Alexander'dan (2010) e-posta ile yasal izin alınmıştur. Ölçeğin yapı geçerliği ve güvenirlik çalışmaları için önce dil yönünden eşdeğerliği sağlanmıştır. Dil geçerliği aşamasında ölçeğin Türk kültürüne uyarlanmasında öncelikle çeviri, geri-çeviri ve uzman görüşü yöntemlerine başvurulmuştur. Daha sonra ölçeğin dil eşdeğerliği için dilsel eşdeğer form uygulaması yapılmıştır. Bu uygulama için her iki dile hakim bir örnekleme hem orijinal dilde olan hem de Türkçeye uyarlanan ölçeğin uygulanması işlemleri gerçekleştirilmiştir (Dincer, Eksi ve Aron, 2018). Bu doğrultuda önce ölçek orijinal dilinde uzman toplam 24 kişi (çeşitli anabilim dallarından İngilizceye hâkim 6 akademisyen, 15 İngilizce öğretmeni, anadili İngilizce olan 1 öğretmen, 2 çevirmen) tarafinca önce Türkçeye; daha sonra yeniden İngilizceye çevirtilerek, geri-çeviri işlemi sağlanmıştur. Bu adımda çeviri yapan kişilerle geri-çeviri yapan kişilerin aynı kişiler olmamasına dikkat edilmiştir. Uzmanlardan alınan öneriler doğrultusunda ölçeğin maddeleri düzeltilerek, dört farklı Türk Dili ve Edebiyatı uzmanı tarafindan dilbilgisi ve anlam açısından inceletilmiştir. İncelemeler doğrultusunda gereken düzenlemeler yapılarak Türkçe formun taslağı oluşturulmuştur (Sousa ve Rojjanasrirat, 2011). Bu doğrultuda hazırlanan form, İngilizceye ileri düzeyde hâkim ve orijinal dilini etkin kullanan 160 İngilizce öğretmenine iki hafta ara ile (01.01.2018-15.01.2018) uygulanmıştır. Bu iki uygulama sonucundaki puanların, dilsel eşdeğerlik için ölçüt olarak ilişkili örneklemler t Testi ile Pearson çarpım momentler korelasyon analizi yapılarak karşılaştırılması yoluna gidilmiştir.

Tablo 1. Öğretmenin Okulda Kalma Tutumu Ölçeği İngilizce ve Türkçe Formları Arasındaki İlişki

\begin{tabular}{|c|c|c|c|c|c|}
\hline Ölçek & Uygulama & $\mathbf{N}$ & $\bar{X}$ & $\mathbf{S}$ & $\mathbf{r}$ \\
\hline Öğretmenin Okulda & İngilizce & 160 & 3,87 & 0,51 & \\
\hline Kalma Tutumu Ölçeği & Türkçe & 160 & 3,87 & 0,47 &, $915^{* *}$ \\
\hline
\end{tabular}

Tablo 1'e göre İngilizce ile Türkçe uygulamalar arasında bulunan ilişki ile ilgili korelasyon katsayısı çok yüksek düzeyde $(\mathrm{r}=, 915)$ bulunmuştur. Korelasyon katsayısının +1'e yaklaşmasının pozitif yönlü yüksek bir ilişkiyi ifade ettiği bilinmektedir (Hui, 2019; Kilmen, 2015). Bu nedenle, korelasyon değerinin istatistiksel olarak anlamlı olması ölçeğin dilsel eşdeğerlik gösterdiğini kanitlamaktadır.

Öğretmenin okulda kalma tutumu ölçeğinin iki ölçümünün tekrarlı ortalamalarının karşılaştırılarak İngilizce ile Türkçe formlarının arasında ölçeğin genelinde anlamlı fark olup olmadığ1 Tablo 2'de ilişkili örneklemler t Testi ile gösterilmiştir. 
Kaya, A., \& Argon, T. (2019). Öğretmenin Okulda Kalma Tutumu Ölçeğinin Türk Kültürüne uyarlanması: Geçerlik ve güvenirlik çalışması. Journal of Human Sciences, 16(4), 1180-1196. doi:10.14687/jhs.v16i4.5801

Tablo 2. Öğretmenin Okulda Kalma Tutumu Ölçeği Dilsel Eşdeğerlik t Testi Tablosu

\begin{tabular}{lcccccc}
\hline $\begin{array}{l}\text { Öğretmenin Okulda } \\
\text { Kalma Tutumu Ölçeği }\end{array}$ & $\mathbf{N}$ & $\overline{\mathbf{x}}$ & $\mathbf{S}$ & $\mathbf{t}$ & sd & $\mathbf{p}$ \\
\hline Toplam Ölçek & 160 & 43,87 &, 493 &, 000 & 159 & 1,000 \\
\hline$* * \mathrm{p}>.05$ & & & & & &
\end{tabular}

$\mathrm{Bu}$ uygulamada öğretmenin okulda kalma tutumu ölçeğinin tekrarlı olan iki ölçümünün ortalamalarına bakıldığında İngilizce ile Türkçe formlarının arasında anlamlı farkın olup olmaması ilişkili örneklemler t Testi ile sınanmış ve ölçeğin genelinde anlamlı fark olmadığı görülmüsstür (p>.05).

\section{4. Öğretmenin Okulda Kalma Tutumu Ölçeğinin Geçerlik ve Güvenirlik Çalışmaları}

Ölçeğin yapı geçerliğini belirlemede Açımlayıcı Faktör Analizi (AFA) ve Doğrulayıcı Faktör Analizi (DFA) uygulanmış; güvenirliği belirlemede Cronbach Alpha güvenirlik katsayısı, madde toplam korelasyonlanı, Alt-Üst gruplar arası farkın anlamlllı̆̆ ve maddeler arasında olan ilişki hesaplanmıştır.

Yapı geçerliğini kanıtlamak için kullanılan faktör analizi, ölçek uyarlama çalışmalanında sıklıkla tercih edilen yöntemlerden biridir (Büyüköztürk, 2009; Çokluk, Şekercioğlu ve Büyüköztürk, 2018). Alanyazın da bu durumu destekler niteliktedir (Crocker \& Algina, 1986; Diemen, Szobot, Kessler \& Pechansky, 2007; O’Rourke \& Hatcher, 2013; Pedhazur \& Pedhazur Schmelkin, 1991; Williams, Onsman \& Brown, 2010). Faktör analizinde açımlayıcı ve doğrulayıcı olmak üzere iki tür analizden söz edilmektedir (Kline, 2014; Neumann, Kosson \& Salekin, 2017; Singh, 2007). Açımlayıc1 faktör analizinde bir faktör modeli veya yapısı belirlemek için bir grup değişken kullanılır ve daha fazla değişkenden daha az faktör üretmeye çalışlır (Bandalos, 1996). Doğrulayıcı faktör analizi ise açımlayıcı faktör analizinin tersine teori üreten değil teoriyi test eden bir model olarak kullanılmaktadır (Henson \& Roberts, 2006).

Öğretmenin okulda kalma tutumu ölçeğine ilişkin ilk olarak Tablo 3’te görüldüğü gibi madde analizi sonuçlarına bakılmıştır. Bu aşamada bir madde diğer maddelerle ilişkisinde ,30'un altında değilse yeterli olduğu (Eroğlu, 1998; Seçer, 2015); ancak daha hassas çalışmalarda ,45 alınmasının (Büyüköztürk, 2009; Kerlinger, 1973) güvenirliği arttıracağı bilinmektedir. İlk yapılan analizin sonuçları aşağıdaki gibidir.

\begin{tabular}{ccccc}
\multicolumn{4}{c}{ Tablo 3. Öğretmenin Okulda Kalma Tutumu Ölçeği Maddeleri İle İlgili İstatistikler } \\
\hline $\begin{array}{c}\text { Madde } \\
\text { No }\end{array}$ & $\begin{array}{c}\text { Madde } \\
\text { Ortalamas1 }\end{array}$ & $\begin{array}{c}\text { Madde Standart } \\
\text { Sapması }\end{array}$ & $\begin{array}{c}\text { Madde Toplam } \\
\text { Korelasyonu }\end{array}$ & $\begin{array}{c}\text { Madde Silme } \\
\text { Güvenirlik } \\
\text { Katsayıs }\end{array}$ \\
\hline $\mathbf{1}$ & 28,533 & 22,219 & 0,699 & 0,871 \\
$\mathbf{2}$ & 28,525 & 22,315 & 0,667 & 0,874 \\
$\mathbf{3}$ & 28,475 & 21,699 & 0,735 & 0,867 \\
$\mathbf{4}$ & 28,393 & 23,983 & 0,575 & 0,883 \\
$\mathbf{5}$ & 28,850 & 21,662 & 0,611 & 0,883 \\
$\mathbf{6}$ & 28,628 & 21,944 & 0,769 & 0,865 \\
$\mathbf{7}$ & 28,638 & 21,981 & 0,685 & 0,873 \\
$\mathbf{8}$ & 28,230 & 24,208 & 0,584 & 0,882 \\
\hline
\end{tabular}

Genel Güvenirlik $(\alpha)=0,889$

Tablo 3 incelendiğinde, öğretmenin okulda kalma tutumu ölçeğinde ,45’in altında madde olmadığından ölçekten madde çıkarımı yapılmamıştır. Ölçeğin iç tutarlıı̆̆ının belirlenmesinde Cronbach's Alpha analizi kullanılmış olup; bu değerin 1'e yaklaşması güvenirliğin artması anlamına gelmektedir (Liu, 2003; Tavakol \& Dennick, 2011). Bu durumda ölçeğin genel güvenirlik seviyesi yüksek düzeyde bulunmuştur $(\alpha=0,889)$. 
Kaya, A., \& Argon, T. (2019). Öğretmenin Okulda Kalma Tutumu Ölçeğinin Türk Kültürüne uyarlanması: Geçerlik ve güvenirlik çalışması. Journal of Human Sciences, 16(4), 1180-1196. doi:10.14687/jhs.v16i4.5801

$\mathrm{Bu}$ aşama sonrası değişkenlerin toplam ölçekle arasında olan ilişki incelenmiş; bu anlamda r>,30 düzeyinde olan ilişkilerde veri seti faktör analizine uygundur şeklinde yorumlama yapılmıştır. Tablo 4'e göre, ölçek maddeleriyle toplam ölçek arasında bulunan ilişki sözü edilen ölçütü karşlamaktadır. Tablo 4'e göre maddelerle toplam ölçek arasında bulunan ilişkiler ,667-,831 aralığında değişmektedir. Bununla birlikte, matriste sunulan ilişkilerin tamamı $\mathrm{p}<, 01$ düzeyinde anlamlıdır. $\mathrm{Bu}$ bulgulara göre ölçek maddelerinin toplam puanla ilişkisinin yüksek olduğu; maddelerde tutarllık yönünden problem olmadı̆̆ görülmektedir.

Tablo 4. Öğretmenin Okulda Kalma Tutumu Ölçeği Madde ve Toplam Ölçek Korelasyonu Değerleri

\begin{tabular}{ccc}
\hline Madde No & $\mathbf{r}$ & $\mathbf{p}$ \\
\hline $\mathbf{1}$ &, 779 &, $000^{* *}$ \\
$\mathbf{2}$ &, 756 &, $000^{* *}$ \\
$\mathbf{3}$ &, 810 &, $000^{* *}$ \\
$\mathbf{4}$ &, 667 &, $000^{* *}$ \\
$\mathbf{5}$ &, 729 &, $000^{* *}$ \\
$\mathbf{6}$ &, 831 &, $000^{* *}$ \\
$\mathbf{7}$ &, 773 &, $000^{* *}$ \\
$\mathbf{8}$ &, 670 &, $000^{* *}$ \\
\hline$* * \mathrm{p}<, 01$ & &
\end{tabular}

Toplam 8 maddeden oluşan öğretmenin okulda kalma tutumu ölçeğinde, faktör analizindeki ön şartlar olarak ifade edilen değişkenlerin arasında belirli bir oranda korelasyon olmasının sonucu veri setinin faktör analizi için uygunluğu kararını vermek amacı ile KMO değeri, Barlett Küresellik testi ve değişkenlerin arasında olan ilişkiler dikkate alınmahnıştır (Kemani, Grimby-Ekman, Lundgren, Sullivan \& Lundberg, 2019; Pallant, 2007; Tabachnick \& Fidel, 2014). KMO değeri ,60'tan büyük olması veriler üzerinde faktör analizi yapılabileceğini göstermektedir (Büyüköztürk, 2009; Eroğlu, 1998).

Tablo 5. Öğretmenin okulda kalma tutumu ölçeği KMO ve Barlett testi sonucu

\begin{tabular}{llr}
\hline İstatistik & Değer \\
\hline KMO Örneklem Yeterliliği & Ki-kare Değeri $(\chi 2)$ & 0,884 \\
& Serbestlik Derecesi (df) & 1576,706 \\
Bartlett's Küresellik Testi & Anlamlllı Değeri (p) & 28 \\
& & 0,000 \\
\hline
\end{tabular}

Tablo 5’te görüldüğü üzere ,884 $(>, 60)$ ve Barlett küresellik testi $(p<0,01)$ anlamlı çıkmıştır. Bulgulara göre örneklem büyüklüğü faktör analizi yapmaya uygundur; ayrıca verilerin çok değişkenli normal dağılımdan geldiğini kanıtlamaktadır (Kan ve Akbaş, 2005). Sonraki süreçte AFA'da faktör çıkarımının yapılması için Temel Bileşenler Analizi tercih edilmiş; dikey döndürme yöntemlerinden varimax dik döndürme yöntemi kullanılmıştır (Can, 2017). Ölçekte yer alan maddelerin kalma yahut kalmamasına karar vermek için faktör yük değerlerinin ,45 ya da üzerinde bir değer alması ölçüt kabul edilmiştir (Büyüköztürk, 2009; Kline, 2000). Bunun yanında maddelerin tek bir faktör altında yük değeri taşıması da incelenmiştir. 8 maddelik ölçeğin faktör analizinin sonunda toplam varyansın \%56,902'sini açılayan; tek faktörlü olan bir yapının olduğu görülmüştür. Tablo 6'da analize yönelik bulgular sunulmuştur. 
Kaya, A., \& Argon, T. (2019). Öğretmenin Okulda Kalma Tutumu Ölçeğinin Türk Kültürüne uyarlanması: Geçerlik ve güvenirlik çalışması. Journal of Human Sciences, 16(4), 1180-1196. doi:10.14687/jhs.v16i4.5801

Tablo 6. Öğretmenin Okulda Kalma Tutumu Ölçeğinin Öz Değerleri ve Açıkladığı Varyans

\begin{tabular}{cccccc}
\hline & \multicolumn{3}{c}{ Başlang1ç } & \multicolumn{3}{c}{ Döndürme Sonras1 Yüklerin } \\
Kareler Toplamı
\end{tabular}

Tablo 6'dan anlaşılacağı üzere, öğretmenin okulda kalma tutumu ölçeği tek faktörlü öz değeri 1,00'dan büyük olan bir yapı oluşturmaktadır. Faktörün kendi başına ölçeğin \%56,902'sini açıkladığ1 belirlenmiştir. Açıklanan varyansın $\% 30$ ve fazlasının tek faktörlü ölçeklerde yeterli olduğu bilinmektedir (Çokluk, Şekercioğlu ve Büyüköztürk, 2016). Bu durumda toplam varyansın oldukça yeterli olduğu söylenebilir. Faktör yapısının doğrulanması amacıyla değerlendirme yapılan diğer bir nokta da ölçeğe ait çizgi yamaç (Scree plot test grafiği) grafiğidir. Grafik 1'de dördüncü boyut sonras1 kırılmanın gerçekleşmiş olduğu ve bütün maddelerin faktör yapısı açısından bütünlük sağladığı açıkça ortadadir.

\section{Grafik 1. Öğretmenin Okulda Kalma Tutumu Ölçeği Scree Plot Test Sonucu}

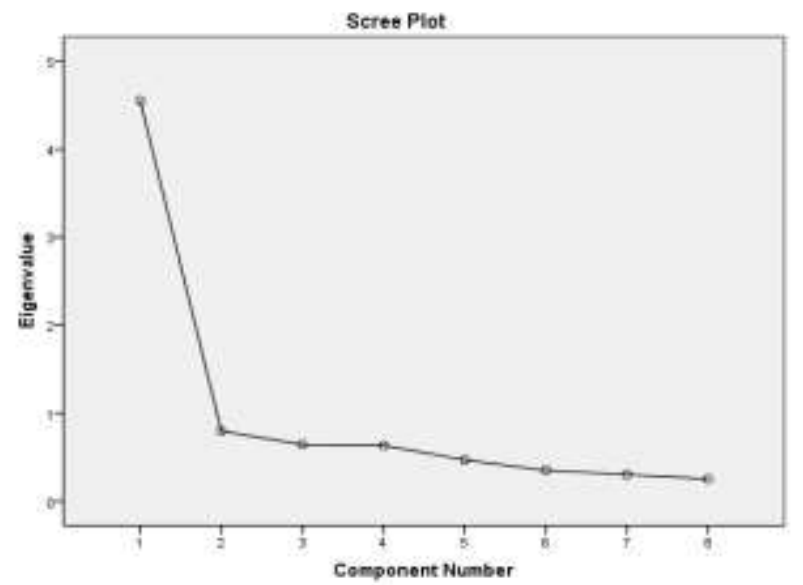

Ölçekteki maddelerin hangi faktörün altında yer aldığını belirlemek için maddenin faktörle ilişkisini ortaya koyan faktör yük değerine bakılmıştır.

\begin{tabular}{ccc}
\multicolumn{2}{c}{ Tablo 7. Öğretmenin } & Okulda Kalma Tutumu Ölçeği Maddeleri Faktör Yük Değerleri \\
\hline Madde No & Ortak Faktör Varyansi & Faktör 1 \\
\hline $\mathbf{1}$ & 0,611 & 0,781 \\
$\mathbf{2}$ & 0,571 & 0,756 \\
$\mathbf{3}$ & 0,656 & 0,810 \\
$\mathbf{4}$ & 0,450 & 0,671 \\
$\mathbf{5}$ & 0,496 & 0,704 \\
$\mathbf{6}$ & 0,697 & 0,835 \\
$\mathbf{7}$ & 0,603 & 0,777 \\
$\mathbf{8}$ & 0,468 & 0,684 \\
\hline
\end{tabular}

Tablo 7'de ortak faktör yük değerleri, döndürme sonrası oluşmuş faktör yapısı ve faktör yük değerleri görülmektedir. Bulguların değerlendirilmesinde ortak faktör yük değerinin $>, 20$ (Tabachnick \& Fidell, 2014); faktör yük değerinin >,45 (Çokluk, Şekercioğlu ve Büyüköztürk, 2016) ve iki faktör yük değerinin arasında olan farkın en az >,10 (Büyüköztürk, 2009) olmasına dikkat edilmiştir. 
Kaya, A., \& Argon, T. (2019). Öğretmenin Okulda Kalma Tutumu Ölçeğinin Türk Kültürüne uyarlanması: Geçerlik ve güvenirlik çalışması. Journal of Human Sciences, 16(4), 1180-1196. doi:10.14687/jhs.v16i4.5801

Tablodan anlaşıldığı gibi ortak faktör yük değerleri ,450 ile ,697 arasında; faktör yük değerleri ise ,671 (Madde 4) ile ,835 (Madde 6) arasında değişmektedir. Ayrıca faktör yük değerleri arasındaki farkların >,100 olması nedeniyle faktörler arasında binişiklik olmadığ1 görülmüştür. Özet olarak, değerlendirilen ölçütler bakımından problemli maddeye rastlanılmamış; maddelerin faktörler altındaki uzaklıkları ve faktör yüklerinin düzeyine göre madde çıkarımı yapılması ihtiyacı duyulmamıştır.

Tablo 8. Öğretmenin Okulda Kalma Tutumu Güvenirlik Analizi Katsayıları

\begin{tabular}{cccc}
\hline Faktör & Madde Sayıs1 & $\overline{\mathbf{x}}$ & $\boldsymbol{\alpha}$ \\
\hline Faktör 1 & 8 & 4,07 &, 889 \\
\hline
\end{tabular}

Tablo 8'e göre, faktör altında toplanan maddeler incelendiğinde (Örneğin; 1. madde: Şu anki okulumda kalabildiğim sürece öğretmenlik yapmaya devam etmeyi planlıyorum. 7. madde: Okulda pozitif bir eğitim ve öğrenim ortamı var ve okulumda eğitim vermeye devam etmeyi planlıyorum.) faktöre ölçeğin genel adı olan "Öğretmenin Okulda Kalma Tutumu" adının verilmesinin uygun olacağına karar verilmiştir. Öğretmenin okulda kalma tutumu ölçeğine ait güvenirlik analizi $(\alpha=, 889)$ sonucunun yüksek düzeyde olduğu belirlenmiştir. Bu bulgulardan yola çıkarak ölçeğin güvenirlik katsayılarının yeterli düzeyde olduğu söylenebilir (Büyüköztürk, 2009; Singh, 2007). Öğretmenin okulda kalma tutumu ölçeğinin, ölçtüğü özellikler bakımından bireyleri ayırt etmekte ne denli yeterli olduğunu tespit etmede madde toplam korelasyonları ile orijinal ölçekte toplam puan üzerinden belirlenen Alt-Üst \%27'lik grup ortalamaları farkını içeren madde analizi yapılmıştır (Büyüköztürk, 2009). Ölçek yoluyla hesaplanmış puanlar ile puanlara göre belirlenmiş olan Alt-Üst \%27'lik gruplar arasında anlamlı fark olup olmadığını tespit etmede bağımsız örneklem t Testi yöntemine başvurulmuştur.

Tablo 9. Öğretmenin Okulda Kalma Tutumu Ölçeği Madde Analizi

\begin{tabular}{|c|c|c|c|c|c|c|c|}
\hline Madde No & Grup & $\mathbf{N}$ & $\overline{\mathbf{x}}$ & $\mathbf{S}$ & $\mathbf{t}$ & $p$ & MTK \\
\hline \multirow{2}{*}{ M1 } & Alt $\% 27$ & 108 & 3,19 & 1,04 & \multirow{2}{*}{$-14,972$} & \multirow{2}{*}{0} & \multirow{2}{*}{0,699} \\
\hline & Üst $\% 27$ & 108 & 4,80 & 0,40 & & & \\
\hline \multirow{2}{*}{ M2 } & Alt $\% 27$ & 108 & 3,22 & 1,04 & \multirow{2}{*}{$-14,395$} & \multirow{2}{*}{0} & \multirow{2}{*}{0,667} \\
\hline & Üst $\% 27$ & 108 & 4,80 & 0,45 & & & \\
\hline \multirow{2}{*}{ M3 } & Alt $\% 27$ & 108 & 3,19 & 1,04 & \multirow{2}{*}{$-16,404$} & \multirow{2}{*}{0} & \multirow{2}{*}{0,735} \\
\hline & Üst $\% 27$ & 108 & 4,91 & 0,32 & & & \\
\hline \multirow{2}{*}{ M4 } & Alt $\% 27$ & 108 & 3,63 & 0,85 & \multirow{2}{*}{$-13,484$} & \multirow{2}{*}{0} & \multirow{2}{*}{0,575} \\
\hline & Üst $\% 27$ & 108 & 4,84 & 0,39 & & & \\
\hline \multirow{2}{*}{ M5 } & Alt $\% 27$ & 108 & 2,76 & 0,98 & \multirow{2}{*}{$-18,387$} & \multirow{2}{*}{0} & \multirow{2}{*}{0,611} \\
\hline & Üst $\% 27$ & 108 & 4,73 & 0,54 & & & \\
\hline \multirow{2}{*}{ M6 } & Alt $\% 27$ & 108 & 3,16 & 0,92 & \multirow{2}{*}{$-17,109$} & \multirow{2}{*}{0} & \multirow{2}{*}{0,769} \\
\hline & Üst $\% 27$ & 108 & 4,81 & 0,40 & & & \\
\hline \multirow{2}{*}{ M7 } & Alt $\% 27$ & 108 & 3,01 & 0,94 & \multirow{2}{*}{$-17,697$} & \multirow{2}{*}{0} & \multirow{2}{*}{0,685} \\
\hline & Üst $\% 27$ & 108 & 4,77 & 0,42 & & & \\
\hline \multirow{2}{*}{ M8 } & Alt $\% 27$ & 108 & 3,75 & 0,84 & \multirow{2}{*}{$-12,077$} & \multirow{2}{*}{0} & \multirow{2}{*}{0,584} \\
\hline & Üst $\% 27$ & 108 & 4,84 & 0,41 & & & \\
\hline
\end{tabular}

$\% 27$ Alt-Üst, t Testi analizi için, $\mathrm{n}=400, \% 27$ için $\mathrm{n} 1=\mathrm{n} 2=108, \mathrm{sd}=214, \mathrm{p}=, 01$

Tablo 9 incelendiğinde, öğretmenin okulda kalma tutumu ölçeği maddelerinin düzeltilmiş madde toplam korelasyonları ,584-,769 aralı̆̆ında değişmektedir. Bu bulgu söz konusu değerlerin istenen düzeyde olduğunu kanıtlar niteliktedir (Büyüköztürk, 2001; Field, 2009). Diğger yandan AltÜst \%27'lik gruplar arasında puan ortalamaları bakımından anlamlı farkların olduğu belirlenmiştir $(\mathrm{p}<, 01)$. Bu bulgular, ölçek maddelerinin iç tutarlılığının yüksek ve bireyleri ayırt etmede yeterli 
Kaya, A., \& Argon, T. (2019). Öğretmenin Okulda Kalma Tutumu Ölçeğinin Türk Kültürüne uyarlanmass: Geçerlik ve güvenirlik çalışması. Journal of Human Sciences, 16(4), 1180-1196. doi:10.14687/ihs.v16i4.5801

olduğunu gösterir niteliktedir. Ölçeğin iç tutarlllı̆̆ bağlamında yürütülen son analiz ise ölçeğin tek boyuttan oluşması nedeniyle toplam ölçek ve maddeleri arasındaki ilişkinin Pearson Korelasyon katsayısı yöntemi ile hesaplanmasıdır. Tablo 10'da analize ilişkin bulgular sunulmaktadır.

Tablo 10. Öğretmenin Okulda Kalma Tutumu Ölçeği ile Maddeleri Arasındaki İlişki

\begin{tabular}{cccccccccc}
\hline Madde No & $\mathbf{1}$ & $\mathbf{2}$ & $\mathbf{3}$ & $\mathbf{4}$ & $\mathbf{5}$ & $\mathbf{6}$ & $\mathbf{7}$ & $\mathbf{8}$ & Toplam Ö. \\
\hline $\mathbf{1}$ & 1 & & & & & & & & \\
$\mathbf{2}$ &, $611^{* *}$ & 1 & & & & & & & \\
$\mathbf{3}$ &, $565^{* *}$ &, $654^{* *}$ & 1 & & & & & & \\
$\mathbf{4}$ &, $468^{* *}$ &, $377^{* *}$ &, $497^{* *}$ & 1 & & & & & \\
$\mathbf{5}$ &, $498^{* *}$ &, $448^{* *}$ &, $534^{* *}$ &, $413^{* *}$ & 1 & & & & \\
$\mathbf{6}$ &, $625^{* *}$ &, $542^{* *}$ &, $567^{* *}$ &, $459^{* *}$ &, $615^{* *}$ & 1 & & & \\
$\mathbf{7}$ &, $504^{* *}$ &, $467^{* *}$ &, $536^{* *}$ &, $425^{* *}$ &, $453^{* *}$ &, $687^{* *}$ & 1 & & \\
$\mathbf{8}$ &, $407^{* *}$ &, $428^{* *}$ &, $501^{* *}$ &, $476^{* *}$ &, $289^{* *}$ &, $487^{* *}$ &, $584^{* *}$ & 1 & \\
Toplam Ö. &, $779^{* *}$ &, $756^{* *}$ &, $810^{* *}$ &, $667^{* *}$ &, $729^{* *}$ &, $831^{* *}$ &, $773^{* *}$ &, $670^{* *}$ & 1 \\
\hline
\end{tabular}
$\mathrm{p}<, 01 ; \mathrm{n}=400$

Tablo 10'da öğretmenin okulda kalma tutumu toplam ölçek ve maddeleri arasındaki Pearson momentler çarpımı korelasyon katsayıları sunulmaktadır. Russo'ya (2004) göre ,100-,290 arasındaki korelasyon katsayıları zayıf; ,300-,499 arasında orta ve ,500 üzerinde ise oldukça güçlü ilişkileri ifade etmektedir. Tablodan da anlaşılacağı gibi, toplam ölçek ile maddeleri arasında anlamlı pozitif yönlü düşük, orta ve yüksek düzeyde ilişkiler mevcuttur. Bu bulgu ölçeğin iç tutarlllı̆̆ının bir diğer göstergesi olarak yorumlanabilir.

Tablo 11'de öğretmenin okulda kalma tutumu ölçeği faktör yapısını test etmek amacıyla yürütülen DFA analizi sonucunda elde edilen madde istatistikleri bulguları yer almaktadır.

Tablo 11. Öğretmenin Okulda Kalma Tutumu Ölçeği DFA Bulgularına İlişkin Madde İstatistikleri

\begin{tabular}{cccccc}
\hline Faktör & Madde & $\begin{array}{c}\text { Faktör Yük } \\
\text { Değeri }\end{array}$ & $\mathbf{R}^{2}$ & $\begin{array}{c}\text { Hata } \\
\text { Varyans1 }\end{array}$ & $\mathbf{t}$ \\
\hline & $\mathbf{1}$ & 0,73 & 0,53 & 0,47 & $18,72^{* *}$ \\
& $\mathbf{2}$ & 0,07 & 0,00 & 1,00 & 1,6 \\
Öğretmenin Okulda & $\mathbf{3}$ & 0,63 & 0,40 & 0,60 & $15,38^{* *}$ \\
Kalma Tutumu & $\mathbf{4}$ & 0,37 & 0,14 & 0,86 & $8,37^{* *}$ \\
& $\mathbf{5}$ & 0,22 & 0,05 & 0,95 & 4,74 \\
& $\mathbf{6}$ & 0,37 & 0,14 & 0,86 & $8,41^{* *}$ \\
& $\mathbf{7}$ & 0,91 & 0,83 & 0,17 & $25,94^{* *}$ \\
& $\mathbf{8}$ & 0,87 & 0,76 & 0,24 & $24,13^{* *}$ \\
\hline
\end{tabular}

Tablo 11 incelendiğinde, öğretmenin okulda kalma tutumu ölçeğinin AFA sonucunda elde edilen faktör yapısının madde 2 ve madde 5 haricindeki madde istatistikleri açısından DFA bulguları ile de doğrulandığı söylenebilir (Bandalos ve Finney, 2010). Madde 2 ve madde 5'e ait faktör yük değerleri ,10’u altında olduğundan ölçekten çıkartılarak DFA yapılmasına karar verilmiş olup buna göre, maddelerin faktör yük değerleri ,37 (madde 4 ve 6) ile ,91 (madde 7) arasında değişmektedir. Söz konusu değerlerin orta ve yüksek faktör yükü olarak değerlendirilebilir. Öte yandan çoklu korelasyon karesine ilişkin değerler $\left(\mathrm{R}^{2}\right), 14$ (madde 4 ve 6 ) ile ,83 (madde 7) arasında değişmektedir. $\mathrm{Bu}$ bağlamda da $\mathrm{R}^{2}$ değerinin de yüksek ve orta bağlamda olduğu ifade edilebilir (Kline 2009). Maddeler ile örtük değişkenler arasındaki ilişkilerin istatistiksel anlamllık düzeyinin ifadesi olan $t$ 
Kaya, A., \& Argon, T. (2019). Öğretmenin Okulda Kalma Tutumu Ölçeğinin Türk Kültürüne uyarlanması: Geçerlik ve güvenirlik çalışması. Journal of Human Sciences, 16(4), 1180-1196. doi:10.14687/jhs.v16i4.5801

değerleri ise $\mathrm{p}<, 01$ düzeyinde anlamlı bulunmuş ve bütün değerlerin 2,56'dan büyük olduğu görülmüş̧ür. Aşağıda öğretmenin okulda kalma tutumu ölçeği path diyagramı sunulmuştur.

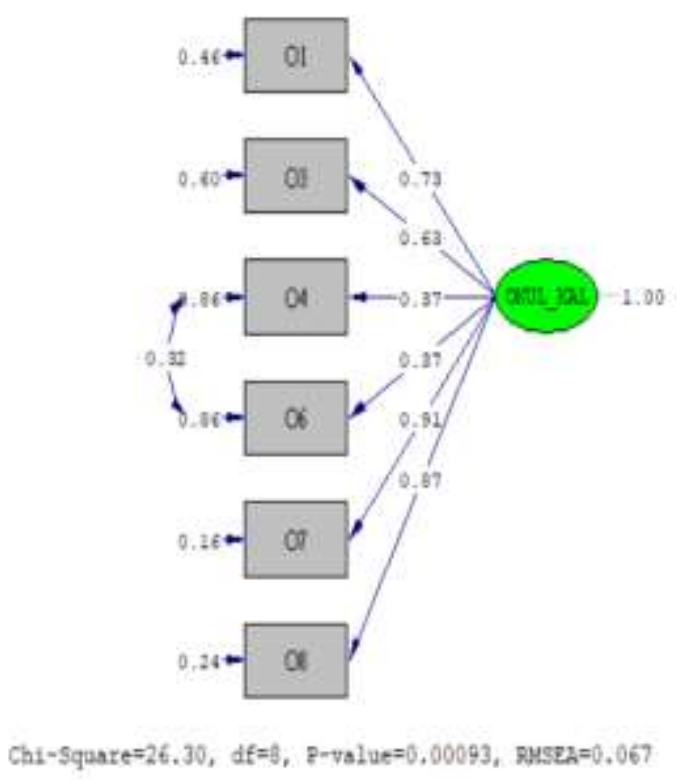

\section{Şekil 1. Öğretmenin Okulda Kalma Tutumu Ölçeği Path Diyagramı}

Tablo 12'de öğretmenin okulda kalma tutumu ölçeği uyum iyiliği değerleri sunulmaktadır. Buna göre modifikasyon öncesi $\mathrm{X}^{2} / \mathrm{df}$, RMSEA ve NNFI değerlerinin istenilen ölçütte olmadığ1; ancak yapılan modifikasyonlardan sonra (Madde 4-6) uyum iyiliği değerlerinin istenilen seviyeye çıktığı görülmektedir. Öte yandan ki-kare değer örneklem büyüklüğünden etkilenen bir istatistiktir ve p değerinin anlamsız olması beklenir. Bu nedenle tek başına bakıldığında anlamlı olup olmama durumundan öte Serbestlik Derecesine (df) olan oran dikkate alınmalıdır. Bu bağlamda $\mathrm{X}^{2} / \mathrm{df}$ oranı 5’ten küçük olursa; ki-kare anlamlı olsa bile modelde genel olarak uyumun kabul edilebilir olduğu anlaşılmaktadır (Brown, 2014; Seçer, 2015). Ayrıca örneklemin nispeten büyük olduğu durumlarda p değerinin anlamlı çıkması olağan bir durumdur (Ullman, 2006). Bu açıdan bakıldığında uyum iyiliği değerlerinin öğretmenin okulda kalma tutumu ölçeğini doğrular nitelikte olduğu söylenebilir.

Tablo 12. Öğretmenin Okulda Kalma Tutumu Ölçeği Uyum İyiliği Değerleri

\begin{tabular}{ccccccccccc}
\hline Modifikasyon & $\mathbf{X}^{2} / \mathbf{d f}$ & $\mathbf{p}$ & $\mathbf{R M S E A}$ & $\mathbf{C F I}$ & $\mathbf{G F I}$ & AGFI & NNFI & NFI & RMR & SRMR \\
\hline Öncesi & 10,97 &, 000 &, 139 &, 950 &, 940 &, 860 &, 910 &, 940 &, 081 &, 074 \\
Sonras1 & 3,29 &, 000 &, 067 &, 990 &, 980 &, 960 &, 980 &, 980 &, 035 &, 028 \\
Normal Değer & $\leq 5$ & $>0.05$ & $\leq 0.05$ & $\geq 0.95$ & $\geq 0.95$ & $\geq 0.95$ & $\leq 1.00$ & $\leq 1.00$ & $\leq 0.05$ & $\leq 0.05$ \\
\hline
\end{tabular}

\section{Bulgular}

\section{1. Öğretmenlerin Okulda Kalma Tutumuna Yönelik Bulgular}

Öğretmenlerin okulda kalma tutumları ile ilgili görüşlerine ilişkin Tablo 13’te aritmetik ortalama ile standart sapma değerleri gösterilmiştir. Betimsel analiz için hem AFA ( $n=400)$ hem de DFA $(n=512)$ verileri birlikte ele alınmıştır. 
Kaya, A., \& Argon, T. (2019). Öğretmenin Okulda Kalma Tutumu Ölçeğinin Türk Kültürüne uyarlanması: Geçerlik ve güvenirlik çalışması. Journal of Human Sciences, 16(4), 1180-1196. doi:10.14687/ihs.v16i4.5801

Tablo 13. Öğretmenlerin Okulda Kalma Tutumlarına İlişkin Betimsel İstatistik Sonuçları
\begin{tabular}{lccc}
\hline Ölçek & $\mathbf{N}$ & $\overline{\mathbf{x}}$ & $\mathbf{S}$ \\
\cline { 2 - 4 } $\begin{array}{l}\text { Okulda Kalma } \\
\text { Tutumu }\end{array}$ & 912 & 3,73 & 0,61 \\
\hline
\end{tabular}

Tablo 13'e göre, öğretmenlerin okulda kalma tutumları görüşlerinin ortalamasının $\overline{\mathbf{x}}=3,73$ değerinde olduğu ve bu değerin "katıliyorum" düzeyine karşıllk geldiği anlaşılabilir. Bu bulguya göre, öğretmenlerin okulda kalma tutumlarına ilişkin görüşlerinin yüksek düzeyde benzer olduğu söylenebilir.

\section{Sonuç, Tartışma ve Öneriler}

Bu çalışmada Joyce Marie Brydson Alexander (2010) tarafindan geliştirilen “Öğretmenin Okulda Kalma Tutumu Ölçeği”nin Türk kültürüne uyarlanması kapsamında dil geçerliğinin, güvenirliğinin ve faktör yapısının incelemesi yapılmıştır. Bu nedenle önce ölçeğin dil bakımından geçerliği sağlanmış; bu amaçla çeviri-geri çeviri ve İngilizce-Türkçe formlanı ölçümlerinin arasındaki ilişkili örneklemler t Testi ile Pearson çarpım momentler korelasyon analizi yapılmıştır. Her iki yöntem de ölçeğin dilsel eşdeğerliğini karşılamıştır. Geçerlik için kapsam geçerliği yapılmış; KMO değeri ve Barlett katsayısı kabul edilebilir değerden daha yüksek olduğu için kapsam geçerliğini sağladığ1 görülmüştür. Ölçeğin yapı geçerliğini test etmek amacıyla iki çalışma grubu kullanılmıştır. İlk çalışma grubu üzerinde AFA ve ikinci çalışma grubu üzerinde modelin doğrulanmasını test eden DFA yürütulmüş̧rü. AFA'da ölçeğin tek boyuttan oluştuğu ortaya konmuştur. DFA'da ölçeğin geçerliği test edilmiş; AFA sonucunda elde edilen faktör yapısı madde 2 ve madde 5 haricinde madde istatistikleri açısından DFA bulguları ile doğrulanmıştır. Bu durumda tek boyutlu ölçek 6 maddeye düşmüsstür. Ölçeğin güvenirliğinin tespiti amacıyla Cronbach Alpha katsayısı yöntemi, madde toplam korelasyonlarının, Alt-Üst \%27’lik gruplar arasında olan farkı hesaplama tekniklerine gidilmiştir. Ölçeğin Cronbach Alpha katsayısının ve madde toplam korelasyonlarının yeterli düzeyde olduğu; AltÜst \%27'lik gruplar arasında olan fark anlaml, ölçeğin geneli ve maddeleri arasında ilişki olduğu belirlenmiştir. Son olarak öğretmenlerin okulda kalma tutumları ile ilgili görüşlerine yönelik aritmetik ortalama ile standart sapma değerleri hesaplanmıştır. Öğretmenlerin okulda kalma tutumları görüşlerinin "katıllyorum" düzeyine karşlık geldiği görülmüsstür. Elde edilen bu bulgular genel olarak yorumlandığında, öğretmenlerin okulda kalma tutumlarının nispeten yüksek olduğu ve görüşlerinin benzerlik gösterdiği düşünülebilir. Doğan ve Boyraz'ın (2018) araştırmasında öğretmenlerin \%46's1 başka bir meslek seçme şansları olsa yine öğretmenlik mesleğini seçeceklerini ifade etmişlerdir. Rehberlik ve eğitim sunan, öğretmenlere daha fazla özerklik tanıyan, çalışma koşulları sağlıklı olan ve öğretmenlerin yönetim tarafindan desteklendiği okullarda (Boyd, Grossman, Ing, Lankford, Loeb \& Wyckoff, 2010) öğretmenlerin okulda kalma tutumları daha yüksektir (Hounshell \& Griffin, 1989; Seyfarth \& Bost, 1986). Öğretmenlerin daha fazla özerkliğe sahip oldukları (Hughes, 2012) ve daha yüksek düzeyde idari destek aldıkları (Liu, 2007; Morrison, 2012) okullarda çalışmak istedikleri literatürde belirtilmiştir. Hughes’in (2012) araştırmasına göre de öğretmenlerin \%83,50'si emekli olana kadar öğretmenlik yapmayı planlamaktadır. Öğretmenin okulda kalma tutumunun yüksek olması güçlü idari destek, daha yüksek öğrenci başarısı, daha az öğrenci disiplini sorunu, daha yüksek maaşlar, artan mesleki gelişim firsatları, okul düzeyinde karar vermede artan öğretmen katılımı, iş birliğine dayalı bir çalışma ortamı ve ortak bir özerklik duygusu ile ilişkilendirilmiştir (Guarino, Santibanez \& Daley, 2006; Ingersoll, 2001). Nitekim benzer şekilde Argon ve Çelik Yılmaz (2018) da öğretmenlerin karara katılımlarının ve çalışma ortamlarının genişletilmesi ile özerklik sağlanmasının öğretmenlerin mesleklerine ilişkin olumlu tutum geliştireceğini ve aidiyetlerinin artacağını ifade etmişlerdir. $\mathrm{Bu}$ sonuçlar birlikte ele alınırsa Öğretmenin Okulda Kalma Tutumu Ölçeği’nin Türk kültürüne uyarlandığında geçerli ve güvenilir bir ölçek olmasını kanıtlar niteliktedir. Sonuç olarak öğretmenler üzerinde yürütülen çalışma doğrultusunda ölçeğin öğretmenlerin okulda kalma tutumları düzeylerini ölçebilecek düzeyde geçerli ve güvenilir bir araç olarak kullanılabileceği söylenebilir. 
Kaya, A., \& Argon, T. (2019). Öğretmenin Okulda Kalma Tutumu Ölçeğinin Türk Kültürüne uyarlanması: Geçerlik ve güvenirlik çalışması. Journal of Human Sciences, 16(4), 1180-1196. doi:10.14687/ihs.v16i4.5801

\section{Kaynakça}

Alexander, J. M. B. (2010). An Examination of Teachers' Perceptions Regarding Constructivist Leadership and Teacher Retention. Unpublished Doctoral Dissertation, Walden University, U.S.A.

Argon, T. ve Çelik Yılmaz D. (2018). Mesleki profesyonellik İle öğretmen liderliğine yönelik öğretmen alg1ları arasındaki İlişki. 27. Uluslararası Ë̆itim Bilimleri Kongresi Kongre Kitabı (ss. 1565-1577). Ankara: Pegem Akademi.

Bandalos, B. (1996). Confirmatory factor analysis. Applied multivariate statistics for the social sciences, 3 , $389-420$.

Boyd, D., Grossman, P., Ing, M., Lankford, H., Loeb, S. \& Wyckoff, J. (2010). The influence of school administrators on teacher retention decisions. American Educational Research Journal, 48(2), 303-333. doi: 10.3102/0002831210380788

Brown, T. A. (2014). Confirmatory factor analysis for applied research. NY: Guilford Publications.

Büyüköztürk, Ş. (2001). Deneysel desenler: Öntest sontest kontrol gruplu desen ve veri analizi. Ankara: Pegem Akademi.

Büyüköztürk, Ş. (2009). Sosyal bilimler için veri analiz̧ el kitabı: İstatistik, araștorma deseni, spss uygulamalar ve yorum (9. Baskı). Ankara: Pegem Yayınları.

Can, A. (2017). SPSS ile bilimsel araștırma sürecinde nicel veri analiz̧i (5. Baskı). Ankara: Pegem Akademi Yayincilik.

Carroll, T. \& Fulton, K. (2004). The true cost of teacher turnover. National Commission on Teaching and America's Future. 16-17. Retrieved April 14, 2018, from http//www. ciconline.org

Crocker, L. \& Algina, J. (1986). Introduction to classical and modern test theory. Holt, Rinehart and Winston, 6277 Sea Harbor Drive, Orlando, FL 32887.

Çokluk, Ö., Şekercioğlu, G. ve Büyüköztürk, Ş. (2016). Sosyal bilimler için çok değiş̧kenli istatistik: Spss ve Lisrel uygulamalar (4. Baskı). Ankara: Pegem Akademi.

Dantonio, M. (2001). Collegial coaching (2nd ed.). Blooming, IN: Phi Delta Kappa International.

Diemen, L. V., Szobot, C. M., Kessler, F. \& Pechansky, F. (2007). Adaptation and construct validation of the Barratt Impulsiveness Scale (BIS 11) to Brazilian Portuguese for use in adolescents. Revista Brasileira de Psiquiatria, 29(2), 153-156.

Dincer, D., Eksi, H. ve Aron, A. (2018). Two new scales in the field of couples and marriage counseling: The inclusion of other in the self scale and Turkish self-change in romantic relationships scale. In SHS Web of Conferences (Vol. 48, p. 01053). EDP Sciences.

Doğan, S. ve Boyraz, F. (2018). Öğretmenlerin öğretmenlik mesleğinin saygınllğına ilişkin alg1 ve görüşlerinin incelenmesi. 13. Uluslararası Eğitim Yönetimi Kongresi Kongre Kitabı, e-kitap e-ISBN: 978-605-4561-66-7 (ss. 415).

Dove, M. (2004). Teacher attrition: A critical American and international educational issue. The Delta Kappa Gamma Bulletin, 71(1), 8-14.

Ellison, J. (Speaker) (2005). Cognitive coaching. (DVD). Laureate Education Inc.

Eroğlu, E. (1998). Çağdaş bir yönetim aracı: Eğitim yönetiminde toplam kalite yönetiminin etkileri. Kurgu dergisi, s:15, 380-392.

Grier, T. B. \& Holcombe, A. (2008). Mission possible. Educational Leadership, 65(7), 25-30.

Guarino, C., Santibanez, L. \& Daley, G. (2006). Teacher Recruitment and Retention: A ReviewoftheRecentEmpiricalLiterature. Review of Educational Research, 76(2), 173-208.

Henson, R. K. \& Roberts, J. K. (2006). Exploratory factor analysis in published research: Common errors and some comment on improved practice. Educational and Psychological Measurement, 66(3), 393-416.

Hounshell, P. B. \& Griffin, S. S. (1989). Science teachers who left: A survey report. Science Education, 73(4), 433-443.

Howard, T. C. (2003). Who receives the short end of the shortage? Implication of the U.S. teacher shortage on urban schools. Journal of Curriculum and Supervision, 18(2), 142- 160. 
Kaya, A., \& Argon, T. (2019). Öğretmenin Okulda Kalma Tutumu Ölçeğinin Türk Kültürüne uyarlanması: Geçerlik ve güvenirlik çalışması. Journal of Human Sciences, 16(4), 1180-1196. doi:10.14687/jhs.v16i4.5801

Hui, E. G. M. (2019). Learn R for applied statistics: With data visualizations, regressions, and statistics. Singapore: Apress. ISBN-13 (pbk): 978-1-4842-4199-8 https://doi.org/10.1007/978-14842-4200-1.

Hughes, G. D. (2012). Teacher retention: Teacher characteristics, school characteristics, organizational characteristics, and teacher efficacy. Journal of Educational Research, 105(4), 245255. DOI:10.1080/00220671.2011.584922.

Ingersoll, R. (2001). Teacher turnover and teacher shortages: An organizational analysis. American Educational Research Journal, 38(3), 499-534.

Johnson S. M., Birkeland, S., Kardos, S. M., Kauffman, D., Liu, E. \& Peske, H. G. (2005). Retaining the next generation of teachers: The importance of school-based support. Harvard Education Letter Focus Series, 17(4), 6-8.

Kan, A., ve Akbaş, A. (2005). A study of developing an attitude scale towards chemistry. Mersin University Journal of the Faculty of Education, 1(2), 227-237.

Kaysi, F. ve Gürol, A. (2016). Öğretmenlik mesleğine yönelik öğretmen görüşlerinin değerlendirilmesi. Ë̆itim ve Ö̆retim Araştırmalar Dergisi, 5(2), 230-240.

Kemani, M. K., Grimby-Ekman, A., Lundgren, J., Sullivan, M. \& Lundberg, M. (2019). Factor structure and internal consistency of a Swedish version of the Pain Catastrophizing Scale. Acta Anaesthesiologica Scandinavica, 63(2), 259-266.

Kerlinger F. N. (1973) Foundation of Behavioral Research. New York: Holt, Rinehart and Winston.

Kilmen, S. (2015). Eg̈itim arasstrmacular için SPSS uygulamah istatistik. Ankara: Edge Akademi.

Kline, P. (2014). An easy guide to factor analysis. Routledge.

Liu, Y. (2003). Developing a scale to measure the interactivity of websites. Journal of Advertising Research, 43, 207-216.

Mancuso, S. V. (2010). An Analysis of the Reasons for Teacher Turnover in American International Schools. Unpublished Doctoral Dissertation, Lehigh University, Betblehem, PA.

Morrison, J. (2012). The principal's role in teacher retention: Keeping new teachers (RETAIN Center of Excellence report). 14.08.2018 tarihinde http://www. retainscteachers.org/wordpress/wpcontent/uploads/2013/10/Morrison-Principals-Rolein-Teacher-Retention-24.pdf sitesinden erişilmiştir.

Neumann, C. S., Kosson, D. S. \& Salekin, R. T. (2017). Exploratory and confirmatory factor analysis of the psychopathy construct: Methodological and conceptual issues. In The Psychopath (pp. 79-104). Routledge.

Orçan, F. (2018). Exploratory and Confirmatory Factor Analysis: Which One to Use First?. Journal of Measurement and Evaluation in Education and Psychology-Epod, 9(4), 414-421.

O'Rourke, N. \& Hatcher, L. (2013). Factor analysis and structural equation modeling. SAS Institute, Cary.

Pallant, J. (2007). SPSS survival manual (3rd.). Edition. McGrath Hill.

Patton, M. (2006). The law of increasing returns: A Process for retaining teachers- National recommendations. National Journal for Publishing and Mentoring doctoral Student Research, 3(1), 19 .

Pedhazur, E. J. \& Pedhazur Schmelkin, L. (1991). Exploratory factor analysis. Measurement, design and analysis: An integrated approach, 590-630.

Russell, A. (2005). The facts and fictions about teacher shortages. American Association of State Colleges and Universities, 2(5), $2-5$.

Russo, R. (2004). Statistics for the behavioural sciences: an introduction. Psychology Press.

Seçer, I. (2015). Psikolojïk test geliştirme ve uyarlama süreci: SPSS ve LISREL uygulamalar. Ankara: Anı Yayıncilik.

Seyfarth, J. T. \& Bost, W. A. (1986). Teacher turnover and the quality of worklife in schools: An empirical study. Journal of Research and Development in Education, 20(1), 1-6.

Singh, K. (2007). Quantitative Social Research Methods. New Delhi: Sage Publications. 
Kaya, A., \& Argon, T. (2019). Öğretmenin Okulda Kalma Tutumu Ölçeğinin Türk Kültürüne uyarlanması: Geçerlik ve güvenirlik çalışması. Journal of Human Sciences, 16(4), 1180-1196. doi:10.14687/jhs.v16i4.5801

Smith, D. L., \& Smith, B. J. (2006). Perceptions of violence: The views of teachers who left urban schools. The High School Journal, 89(3), 34-42.

Sousa, V. D. \& Rojjanasrirat, W. (2011). Translation, adaptation and validation of instruments or scales for use in cross-cultural health care research: A clear and user-friendly guideline. Journal of Evaluation in Clinical Practice, 17, 268-274. DOI:10.1111/j.1365-2753.2010.01434.x

Şekerci, M. ve Aypay, A. (2009). İlköğretim okulu yöneticilerinin yönetim becerileri ile grup etkililiği arasındaki ilişki. Kuram ve Uygulamada Egitim Yönetimi Dergisi, 15(1), 133-160.

Tabachnick, B. G. \& Fidel, L. S. (2014). Using multivariate statistics. USA: Pearson Education Limited.

Tavakol, R. \& Dennick, M. (2011). Making sense of cronbach alpha. International Journal of Medical Education. Vol:2, 53-55.doi: 10.5116/ijme.4dfb.8dfd.

The Learning Point Associates. (2007). Improving teacher retention with supportive workplace conditions. The Center for Comprehensive School Reform and Improvement, 1-4.

Ullman, J. B. (2006). Structural equation modeling: Reviewing the basics and moving forward. Journal of personality assessment, 87(1), 35-50.

Williams, L. (2007). Leaders we have a problem! It is teacher retention. What can we do about it? The Lamar University Electronic Journal of Student Research, 1-10. https:// files.eric.ed.gov/fulltext/ED497436.pdf

Williams, B., Onsman, A. \& Brown, T. (2010). Exploratory factor analysis: A five-step guide for novices. Australasian Journal of Paramedicine, 8(3), 1-13. https://ajp.paramedics.org/index.php/ajp/article/viewFile/93/90

\section{Ekler}

\section{Ek-1}

\section{Öğretmenin Okulda Kalma Tutumu Ölçeği}

\begin{tabular}{|c|c|}
\hline$\frac{\frac{\bar{d}}{d}}{\frac{\partial}{\tilde{g}}}$ & ÖĞRETMENIN OKULDA KALMA TUTUMU ÖLÇEĞİ \\
\hline 1 & $\begin{array}{l}\text { Şu anki okulumda kalabildiğim sürece öğretmenlik yapmaya devam } \\
\text { etmeyi planlıyorum. }\end{array}$ \\
\hline 2 & $\begin{array}{l}\text { Eğitim alanında çalışmaya devam etmeyi ancak bu okuldan ilk firsat } \\
\text { bulduğumda ayrılmayı planlıyorum. }\end{array}$ \\
\hline 3 & $\begin{array}{l}\text { Okul yönetiminden gelen yeterli destek bu okulda eğitim vermeme } \\
\text { yönelik karar verme sürecimi etkiliyor. }\end{array}$ \\
\hline 4 & $\begin{array}{l}\text { Okulum/sınıfim hakkında kararlar verebilme konusunda } \\
\text { yetkilendirilmem bu okulda kalma konusundaki kararımı etkiliyor. }\end{array}$ \\
\hline 5 & $\begin{array}{l}\text { Okulda pozitif bir eğitim ve öğrenim ortamı var ve okulumda eğitim } \\
\text { vermeye devam etmeyi planlıyorum. }\end{array}$ \\
\hline 6 & $\begin{array}{l}\text { Okul yönetimi öğretmenleri profesyoneller olarak değerlendiriyor } \\
\text { ve bu okulda eğitim vermeye devam etmeyi planllyorum. }\end{array}$ \\
\hline
\end{tabular}


Kaya, A., \& Argon, T. (2019). Öğretmenin Okulda Kalma Tutumu Ölçeğinin Türk Kültürüne uyarlanması: Geçerlik ve güvenirlik çalışması. Journal of Human Sciences, 16(4), 1180-1196. doi:10.14687/ihs.v16i4.5801

\section{Ek-2}

\section{Introduction}

\section{Extended English Summary}

A study conducted in the United States of America has demonstrated that it is essential for state and local level policy makers as well as educational advocates to provide high-caliber teachers at classrooms as well as to keep teacher retention at low levels (Johnson, Birkeland, Kardos, Kauffman, Liu \& Peske, 2005). That teachers take the personal and professional pros and cons of retention has been the subject of various studies. These pros and cons might be associated with the relations with the stakeholders in the sector of education, the expectations from the school environment and satisfaction at school and the attitude of other stakeholders, especially that of the leader, along with the expectations regarding salary and other social benefits and rights (Mancuso, 2010). In this sense, the presence of an educational leadership supporting teachers is closely correlated with the increase in the quality of teaching and learning. The educational leaders are required to refrain from traditional leadership practices that hinder the professional development of teachers while they are putting effort to compensate the weaknesses of teachers (Dove, 2004; Ingersoll, 2001; Winans, 2005). Thus, the school administration is responsible for creating the suitable grounds that offer professional development opportunities for teachers. Such an understanding could be one of the factors that help teachers continue at their schools.

The researchers support the attitude of teacher retention as a way of settling the problem of teacher inadequacy (Carroll \& Fulton, 2004). However, a great number of school administrators, as an effective variable in the process, fail to develop effective and efficient strategies to improve teacher retention. In this respect, various researchers are in search of new strategies in order to improve the conditions of teacher retention (Dove, 2004). School administrators could contribute to working conditions of teachers positively by respecting teaching profession and adding them into decisionmaking mechanisms at school as well as by sparing sufficient time that will support them. Teachers who work at positive and challenging schools hold high likelihood of teacher retention (The Learning Point Associates, 2007). This concept used as "employee retention" in literature is identified as "teacher retention" in the literature of education. Thus, the educational administrators at schools could positively contribute to the working conditions of teachers at schools by assigning them sufficient time to prepare for their professions appropriately (SSekerci and Aypay, 2009). Yet, the studies demonstrate that the teachers have higher likelihoods of resuming their professions and retention once the working conditions have been improved (The Learning Point Associates, 2007). Some researchers claim that (Dantonio, 2001; Ellison, 2005) turning school into a learning environment by backing the development of teachers boosts the rates of teacher retention. Constantly changing educational policies, the difficulties in implementation, the deficiencies in physical conditions, the ruined life conditions of teachers, the expectations of parents, the demands of the school administration, the factors that suppress the problems with students to be revealed and many other similar reasons might impact teacher retention behavior negatively. Despite the fact that teacher retention or decision of continuing at teaching profession is not an issue that matters much in Turkey, lack of retention for the schools at obligatory service districts or frequent teacher turnovers at private schools makes the issue worth addressing in Turkey. It is then suggested that the fact that teachers are having hard time switching for an alternative profession could impact this overall picture. This aligns with the finding of a study that teachers will not opt for working as teachers due to the challenges that they have suffered from on the condition that they might find a job having a better status (Kaysi ve Gürol, 2016). Yet, teachers are claimed to be surviving in teaching business despite the formidable requirements of the profession once they have started their teaching careers. Thus, adaptation of Teacher Retention Attitude Scale into Turkish culture via this study is considered significant in that it sets the retention levels; it determines the likely factors that might impact the retention at a school or leaving the school for another school or leaving the profession before 
Kaya, A., \& Argon, T. (2019). Öğretmenin Okulda Kalma Tutumu Ölçeğinin Türk Kültürüne uyarlanması: Geçerlik ve güvenirlik çalışması. Journal of Human Sciences, 16(4), 1180-1196. doi:10.14687/ihs.v16i4.5801

retirement and in that it forms a base by associating it with various other terms in national literature. Thus, Teacher Retention Attitude Scale designed by Brydson Alexander (2010) is expected to be a valid and reliable testing instrument in Turkish culture through its translation and adaptation into Turkish language.

\section{Method}

The study was conducted among teacher working at districts of Kocaeli and Istanbul, Turkey during 2018-2019 academic year (two different working groups). To test the construct validity of the scale, a model was first designed with the first sample group through Exploratory Factor Analysis, and then a Confirmatory Factor Analysis was conducted with the second sample group in order to set if the construct validity would be verified or not. The first working group of the study was formed by 400 teachers working in Kocaeli district while the second group involved 518 teachers from İstanbul district. As a survey tool, "Google forms", one of google applications, was used with working groups.

SPSS for Mac OS 22.0 for Exploratory Factor Analysis and Lisrel 8.7 for Confirmatory Factor Analysis was used and significance level was taken as .05. This study involves the adaptation of Teacher Retention Scale designed by Joyce Marie Brydson Alexander (2010) into Turkish via teachers. To ensure the language validity of the scale during the adaptation into Turkish culture, translation, back-translation and expert opinion methods have primarily been used. A linguistic equivalency form has then been used to ensure the linguistic equivalency of the scale. To test the linguistic equivalency of the scale, English Language Teachers have been used at certain intervals (English-Turkish; Turkish-English) and it has been found that there are positive and meaningful correlations between English and Turkish form scores. It has been demonstrated that the scale owns a unidimensional structure with 6 sections as a result of exploratory and confirmatory factor analysis conducted in order to determine the factor structure of the scale. The total item correlation coefficients of Teacher Retention Scale varies from ,584 to ,769. It has been concluded that these coefficients are as expected. Besides, factor load values have been found around ,671 and ,835. For instance, Cronbach's Alpha internal consistency coefficient has been measured $(\alpha=.889)$. The variation between Upper and Lower groups measured as $27 \%$ has been found meaningful. The factor structure obtained via Exploratory Factor Analysis has been verified by the outcomes of Confirmatory Factor Analysis in terms of item statistics except for item no 2 and item no 5. Confirmatory Factor Analysis suggests that the factor load values vary from ,37 to ,91. These values have been interpreted as medium and high factor loads. In addition, the values regarding multiple correlation (R2) vary from 14 to ,83. Thus, it has been found that R2 value is at high and mediocre levels. It has also been demonstrated that X2/df, RMSEA and NNFI values were not at desired levels prior to modification and that the values of goodness of fit (items 4-6) have been pulled up to desired levels following the modification. It has also been found that retention views levels correspond to "I agree" level.

\section{Conclusion}

In conclusion, Teacher Retention Scale is a unidimensional scale of 6 items as well as a valid and reliable testing instrument. 